\title{
Passion Dance
}

I've thought of you

thirteen times this

week, one; when

taking out the trash, two; when ironing

my unkempt

trousers, three;

when taking a

dump, four: when

puking up my

awful take-away,

five; whilst being

beaten up by

angry adolescents, six; ah, fuck, you

get the point! I've

thought of you at

the bleakest of

moments to ensure

there was beauty

in the darkness that

enveloped me on all

thirteen occasions,

for nobody else is

so fascinating;

nobody else is so

unfathomably

inhuman in their

gorgeousness;

nobody else can

make my passion 
dance the way you can and I

absolutely love you for that. I could never be quite as thankful as I would want in regards to all that you have given me, especially in the darkest of dark moments, like the thirteen I endured this week alone, but I do hope that the smile upon my face, the love inside my heart and the passion in my soul provides to you the appreciative gratitude I feel every second I have the honour of either being in your adoring presence, or having you flourishing in my mind. Since

I have your attention already, allow me to kindly thank you for the thirteen times I will be thankful for your existence in the week to come. Next Friday is the thirteenth after all and that may have thirteen rotten occurrences of its own, bringing the total to twenty six! Twenty six fabulous moments? Wow, I could live with that!

Nicholas McKay 